\title{
A Scanning and Transmission Electron Microscopic Observation of the Fourth Ventricular Floor in the Mouse
}

\author{
Takashi YAMAdoRI and Soroku Yagihashi
}

\author{
Received February 3, 1975
}

\begin{abstract}
Summary. The floor of the fourth ventricle in the mouse was studied by scanning and transmission electron microscopy.

1. The fourth ventricular floor is covered by a simple layer of ependymal cells, the cytoplasm of which is characterized by numerous filaments and scanty ribosomes.

2. The ventricular surface of the ependyma is studded with numerous cilia and abundant microvilli. In the medial part of the ventricle the cilia grow densely and tend to beat posteriorly, whereas in the lateral part they are sparse and most of them beat posteriorly or posteromedially. In the area near the lateral aperture they beat posterolaterally to laterally. Only a few cilia are observable in the median sulcus.

3. The cilium is about $10 \mu \mathrm{m}$ long and is the thickest at the proximal portion except the most proximal stiff looking part (diameter $300 \mathrm{~nm}$ ), slightly tapering near the tip. It ends in a rounded and occasionally bent tip. Its ultrastructure in sections is that of a kinocilium.
\end{abstract}

4. Adjacent cells contact each other forming zonulae occludentes and zonulae adherentes near the surface, and interdigitations in the deeper portion. Usually the surfaces of the cells are separated by about $40 \mathrm{~nm}$.

5. Besides possible lymphocy tes and other wandering cells which are seen occasionally, several multiform supraependymal cells and neuron-like cells are observed on the ventricular surface. They are oval or polygonal cells with bipolar or multipolar processes which presumably coincide with the unmyelinated nerve fiber-like structures seen by transmission electron microscopy. Some of these cells are supposed to be supraependymal cells of unknown nature but some may be included in nerve cells. A few spider form astrocyte-like cells are also recognized.

6. Occasionally protrusions of ependymal cells and that of possible nerve cells underneath the ependymal layer are observable on the ventricular surface. The latter contains numerous mitochondria but its continuation with a nerve cell is not verified. Sometimes small granules of various sizes are found among microvilli by scanning electron microscopy and they are assumed to be substances secreted through the ependyma.

Observation of the ventricular surface in the central nervous system by using the scanning electron microscope has been performed by various investigators such as Dalen et al. (1971), Weindel and Joynt (1972), Itakura (1972), Clementi and Marini (1972), Scott et al. (1972), Noack et al. (1972), Hosoya and Fujita (1973), Hosoya and Fuse (1973), Chamberlain (1973), Nakamura et al. (1973), Coates (1973a, b), Mestres et al. (1974) and Bruni et al. (1974). The ultrastructure of the ependyma and its cilia, using a transmission electron microscope, has been studied by TENNYSON and Pappas (1962), Brightman and Palay (1963), Kohno and Usui (1966), Takeichi (1966), Leonhardt and Lindner (1967), Hirano and Zimmerman (1967), Leonhardt (1968), Leonhardt and Prien (1968), Nakai (1971), Millhouse (1972), Schinko et al. (1972), NoAck et al. (1972), Rohrschneider et al. (1972), Coates (1973b) and Bruni et 
al. (1974). These studies have made it well-known that the surface of almost all parts of the ventricular system are covered by numerous microvilli and cilia projecting from the ependyma. At the same time, the detailed ultrastructural features of the ependyma and cilia are also within the range of knowledge of many researchers. However, their studies brought out many questions to be answered, such as the distribution pattern of the cilia, the direction of their beat, the functions of the microvilliand of the ependyma itself, the nature of supraependymal cells, and the possible direct contact of any nerve cells with the cerebrospinal fluid. Conceiving these questions in mind, the present study deals with the observation of the surface ultrastructure of the fourth ventricle in the mouse by means of both scanning and transmission electron microscopy.

\section{Materials and Methods}

Adult mice of either sex weighing 20 to $35 \mathrm{~g}$ were used. Animals were fixed by a modefied method of the perfusion technique for transmission electron microscopy (YAMADORI and SAITO, 1970). The perfusate used was sodium cacodylate-buffered $6 \%$ glutaraldehyde ( $\mathrm{pH}$ 7.2). Soon after the perfusion the brain was taken out by cutting at the clava. Then the cerebellum was removed and the forebrain was cut apart at the superior colliculus to expose the fourth ventricle. One half of the fourth ventricle was flooded with cacodylate-buffered $2.5 \%$ glutaraldehyde $(\mathrm{pH} 7.2)$ for more than $2 \mathrm{hrs}$ in preparation for scanning electron microscopy. The other half of the ventricle was cut frontally into slender pieces which were further fixed in $6 \%$ glutaraldehyde for $2 \mathrm{hrs}$. The specimens for both scanning and transmission electron microscopy were washed $1 \mathrm{hr}$ in the buffer solution and fixed again with cacodylate-buffered 1\% osmic acid.

The fixed specimens for scanning electron microscopy were dehydrated through an ascending series of ethanol and flooded with isoamylacetate. Then, the specimens were dried with JCPD-3 type critical point drying equipment. The specimen surfaces coated by vacuum evaporation of carbon and gold (BARBER and BoYDE, 1968) were observed and photographed with a JSM-U3 type scanning electron microscope (accelerating voltage: $25 \mathrm{kV}$ ).

The specimens for transmission electron microscopy were dehydrated through an ascending series of ethanol and embedded in Maraglas 655. Ultrathin sections were obtained by Porter-Blum MT-1 or MT-2B type ultramicrotome and were stained by uranylacetate and lead citrate. A Hitachi HU-12AS type electron microscope was used for the observation.

\section{Observations}

\section{Scanning electron microscopy}

The surface of the fourth ventricle is covered with thick-grown cilia, which project from the apical surface of each ependymal cell, except the surface of the median sulcus where only a few cilia are seen overlying numerous microvilli (Fig. 1, 2). The distribution of cilia is dense in the medial part of the ventricular floor, but it is sparse in the lateral part (Fig. 1). The cilia bend posteriorly in the medial part, while the direction of beat seems complicated in the lateral part, most of them bending posteriorly or posteromedially. Near the lateral aperture they seem to beat posterolaterally to laterally and in the lateral aperture laterally (Fig. 1, 2). The length of 

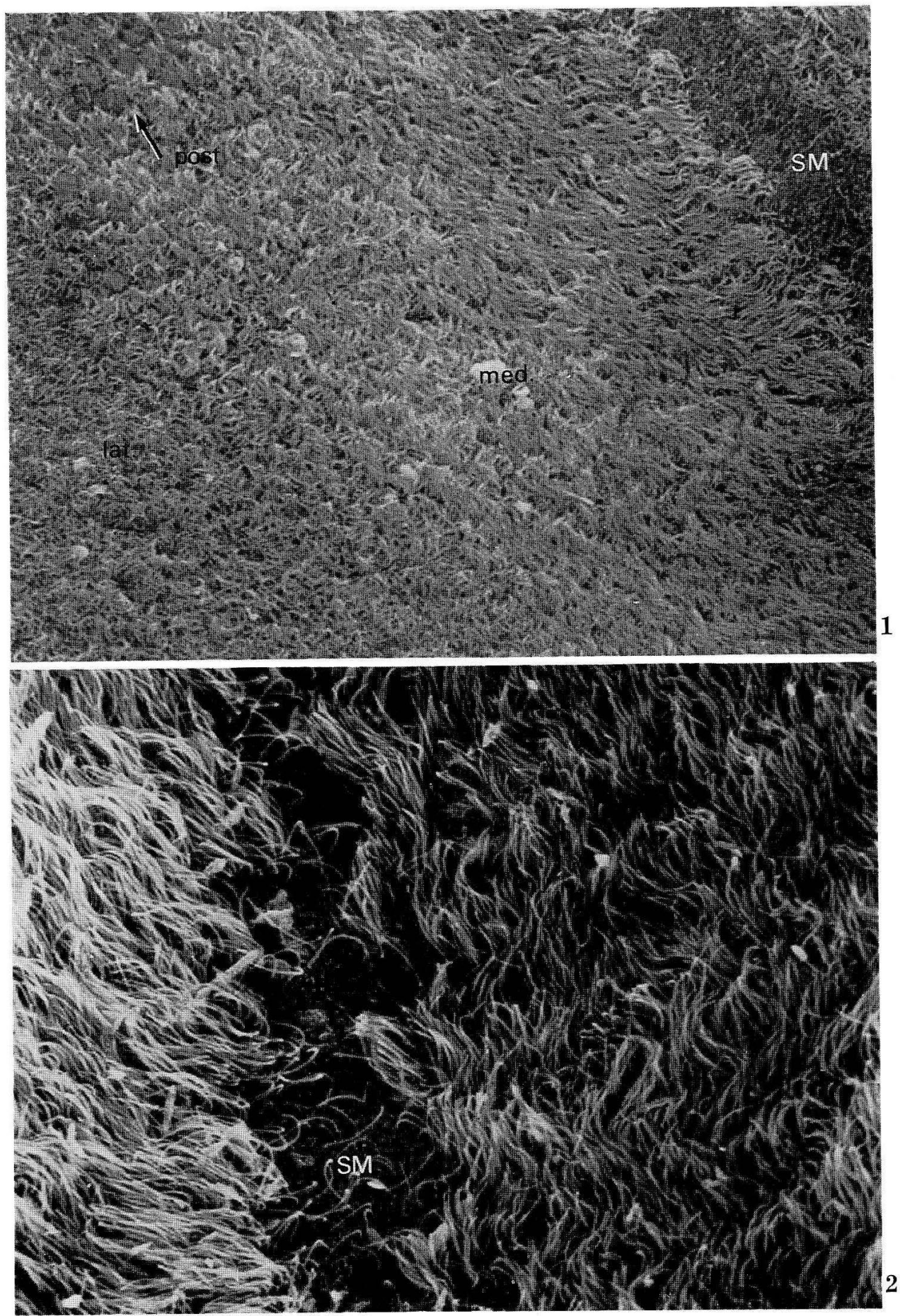

Fig. 1. Low power SEM view of the floor of the fourth ventricle. An arrow shows the posterior direction. SM sulcus medianus, med medial part, lat lateral part. $\quad \times 450$

Fig. 2. Sulcus medianus $(S M)$ where cilia are few, and its neighbouring area. $\times 1,250$ 


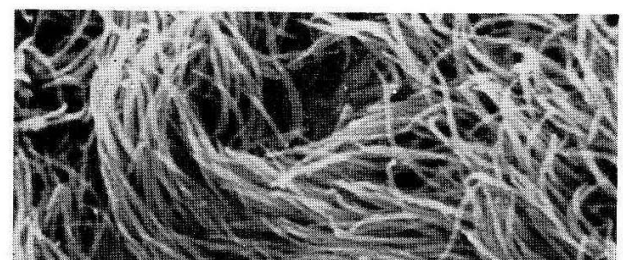

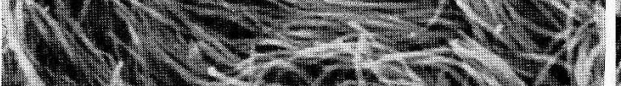

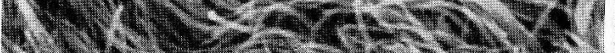

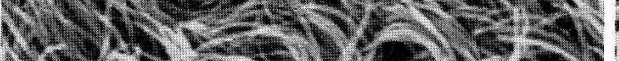

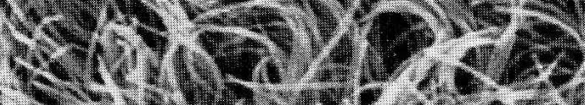
201.

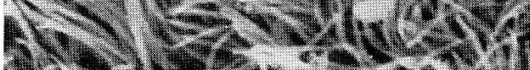

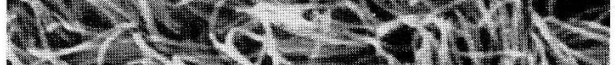

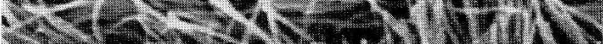

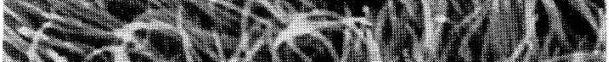

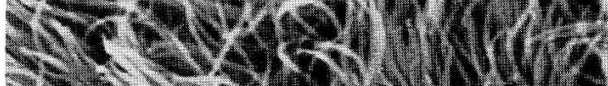

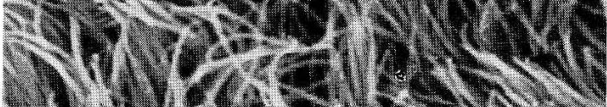
C)

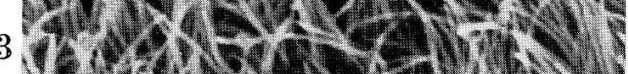
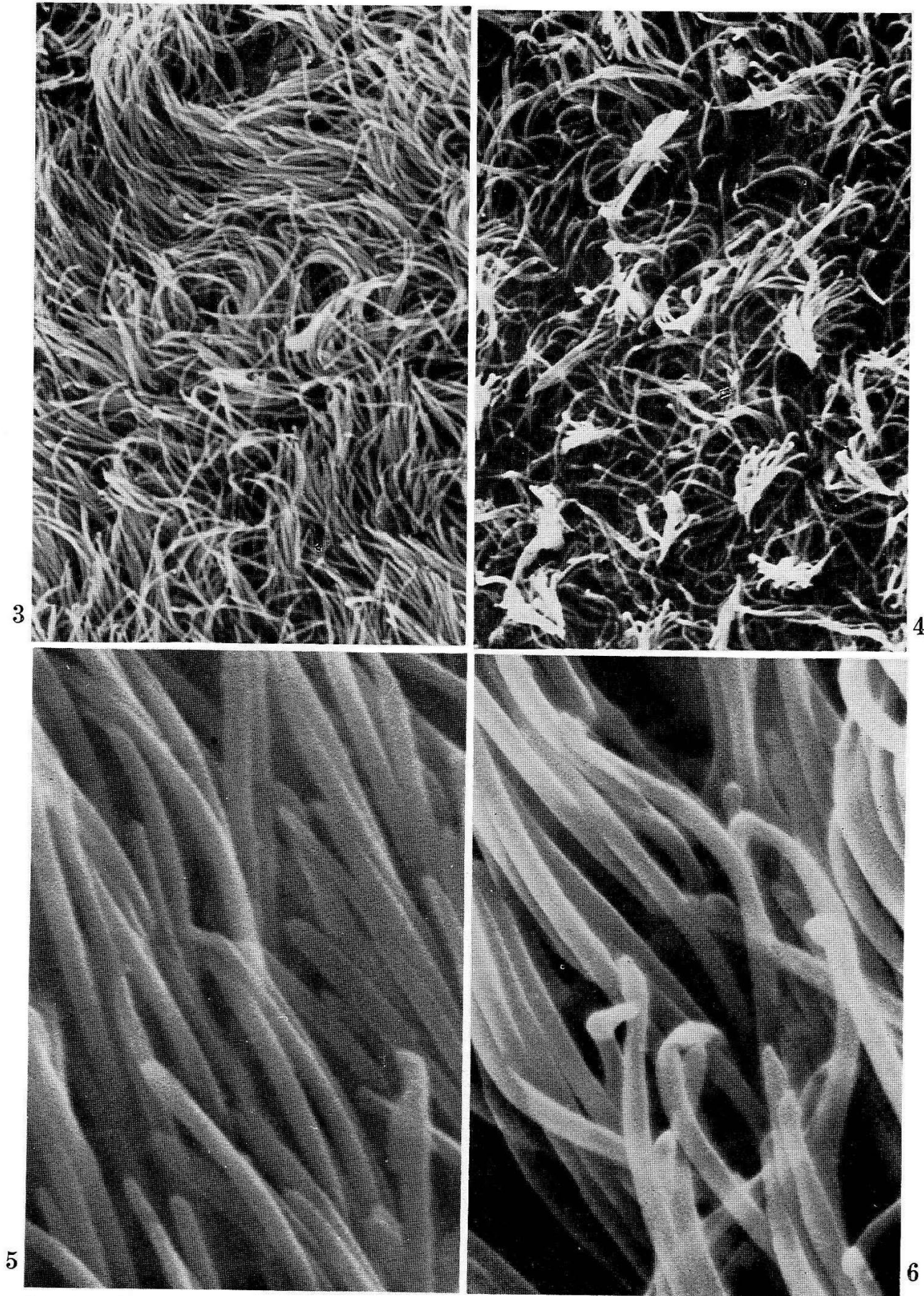

Fig. 3. Cilia in the medial part of the fourth ventricular floor. The distribution of cilia is dense. 
the cilium is around $10 \mu \mathrm{m}$ or more and their maximum diameter is approximately $300 \mathrm{~nm}$. They are more slender at the tip and end blunt (Fig. 5); sometimes they are slightly bent near the tip (Fig. 6). Rarely an oblate spoon-like swelling is also seen at the tip (Fig. 8, arrow), though the possibility that this is a swelling of another cellular process cannot be excluded. A relatively thick fiber which has a diameter of 1.0 to $3.0 \mu \mathrm{m}$ and is supposed to be Reissner's fiber, is frequently seen running anteroposteriorly along the median sulcus (Fig. 7, arrows).

Abundant microvilli are seen in the median sulcus of the ventricular floor where the cilia are sparse (Fig. 8, 9). Although the microvilli protrude from the whole ventricular surface of the individual ependymal cells, they are scarcely observable, being covered with numerous overlying cilia. The diameter of the microvilli is about 50 to $90 \mathrm{~nm}$ and their length around $1.5 \mu \mathrm{m}$. Their surface is somewhat uneven but no fusion of individual microvilli is found. Many spherical structures having a rough surface and a diameter of about 0.7 to $2.0 \mu \mathrm{m}$ are sometimes observed among or upon the microvili (Fig. 9). The nature of these spherules is not clear but it is very likely that they are substances secreted through the ependyma.

Cellular structures are also observable on the floor of the fourth venrtricle. The

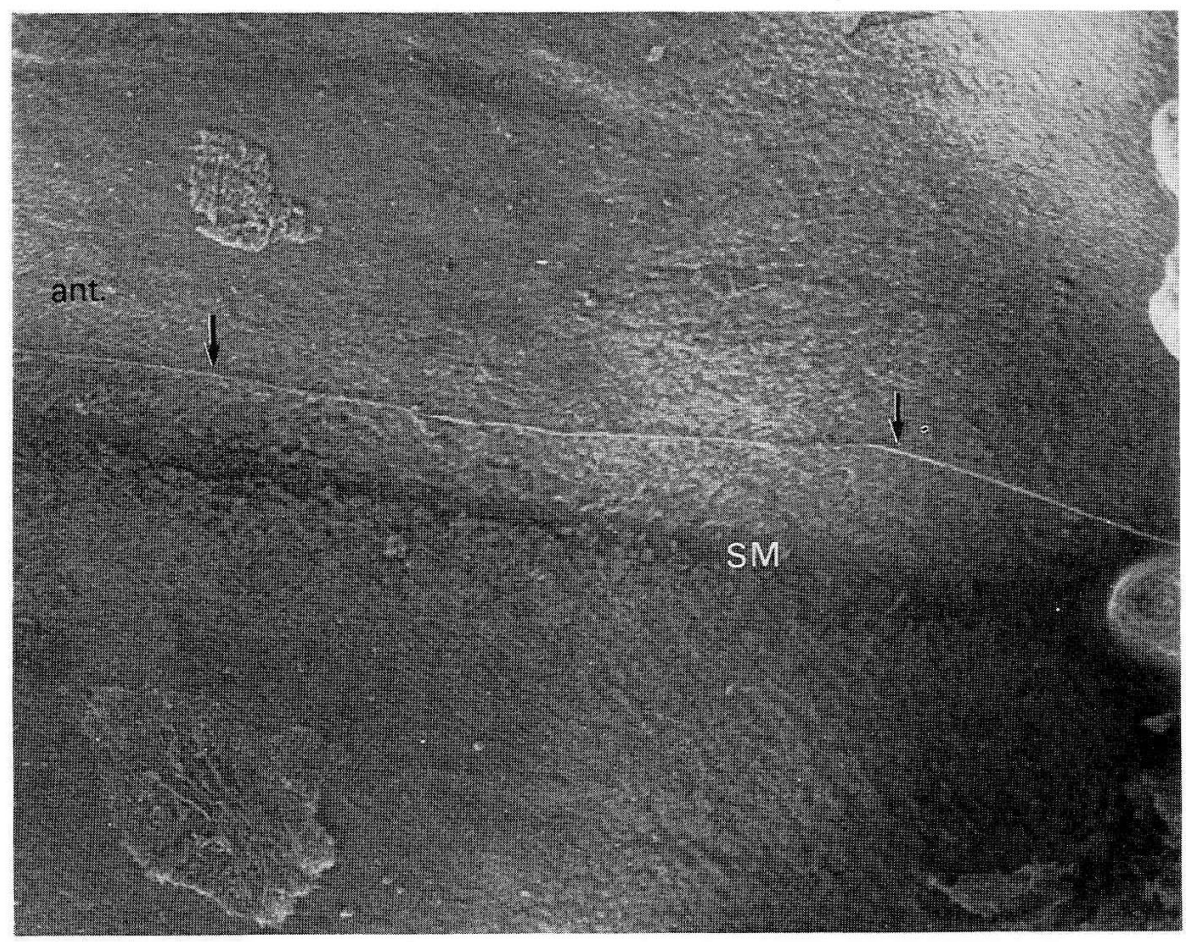

Fig. 7. A possible Reissner's fiber (arrows) along the sulcus medianus $(S M) . \quad \times 125$

Fig. 4. Cilia in the lateral part of the fourth ventricular floor. The distribution of cilia looks sparse. $\times 2,200$

Fig. 5. High power SEM view of cilia showing the round and blunt end. $\times 11,000$

Fig. 6. High power SEM view of cilia showing slight bending of the end. $\times 11,000$ 

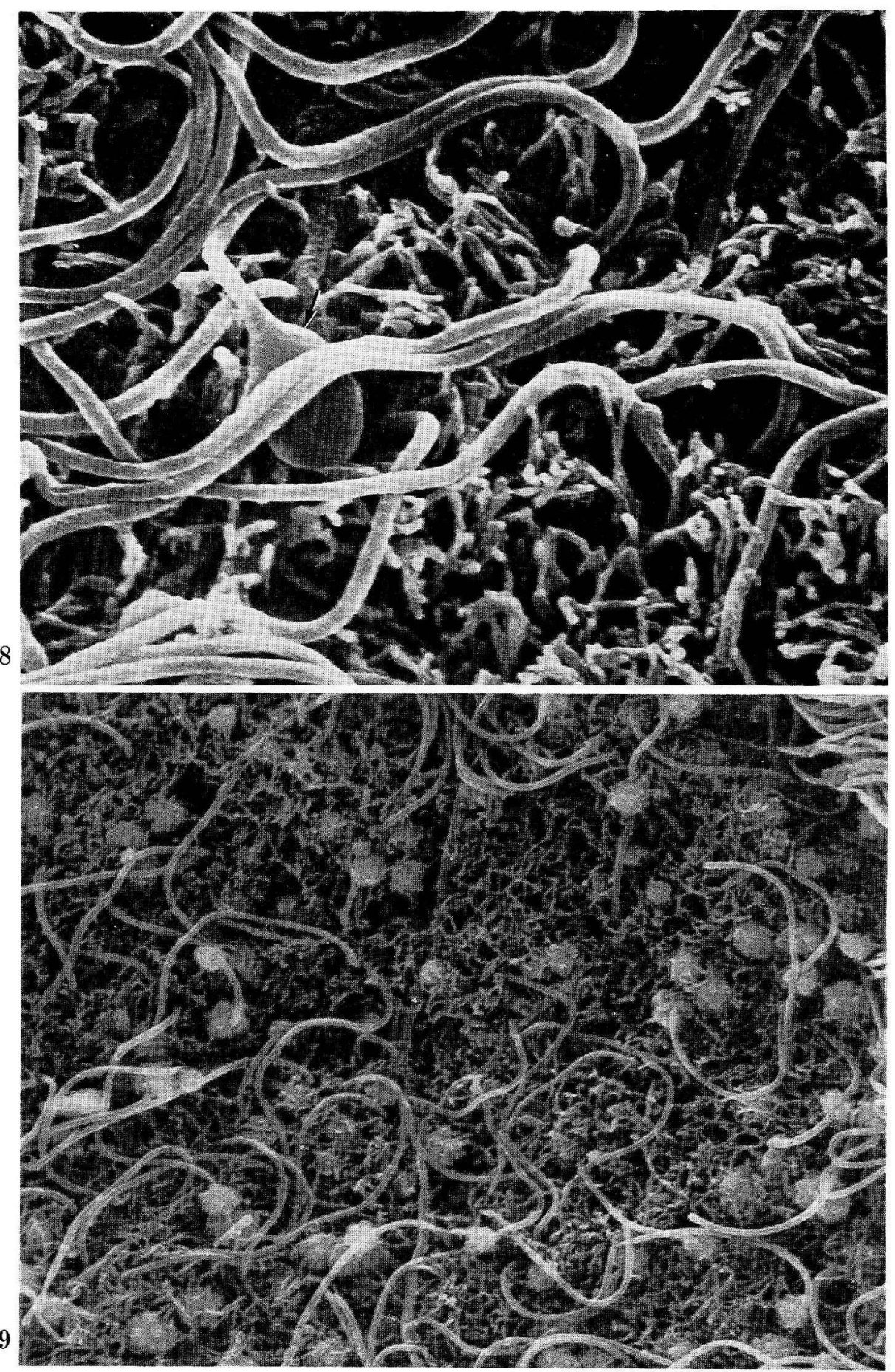
most frequent ones are smooth surfaced spherical cells of a diameter of about 3.0 to $4.0 \mu \mathrm{m}$ and are thought to be smooth lymphocytes (Fig. 10). Very rarely a larger round cell is recognized. This probable leucocyte is not thought to occur constantly in the ventricle. A few cells found constantly in the ventricular floor are the so-called supraependymal cells (Fig. 11) and neuron-like cells (Fig. 12). It is diffiult to differentiate these cells only by their sizes because both of them are around 6 to $8 \mu \mathrm{m}$ in diameter. CoAtes (1973a, b) called multipolar cells in the third ventricle of monkeys supraependymal cells (Fig. 11). However, as to the fourth ventricle in mice it seems more reasonable to conceive that the cells which have bipolar or tripolar axon- or dendrite-like processes are neurons (Fig. 12), than to classify them into supraependymal cells of unknown nature. A few spider form astrocyte-like cells are also recognized.

\section{Transmission electron microscopy}

A simple layer of cuboidal ependymal cells line the ventricular floor. They seem more flat in the lateral area where the distribution of cilia is sparse. The nucleus of the ependymal cell is round or oval and has a relatively light nucleoplasm which contains dark chromatin (Fig. 13). The cytoplasm of the ependyma is rather low in electron density due to the paucity of both free and endoplasmic reticulumadhering ribosomes and surplus filaments. Some vesicles and a few microtubules are

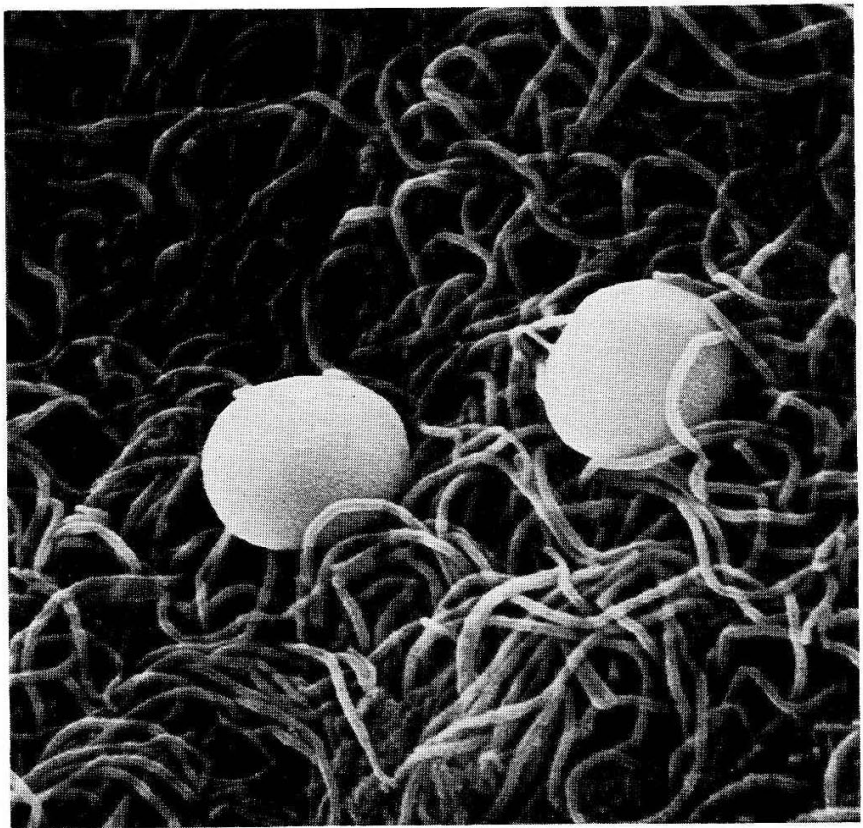

Fig. 10. A couple of smooth surfaced free cells supposed to be smooth lymphocytes. $\times 7,500$

Fig. 8. A spoon-like oblate swelling (arrow) in the sulcus medianus. Numerous microvilli with slight swelling of the end are also seen. $\quad \times 12,500$

Fig. 9. Spherical granules of various sizes in the sulcus medians. $\times 3,750$ 


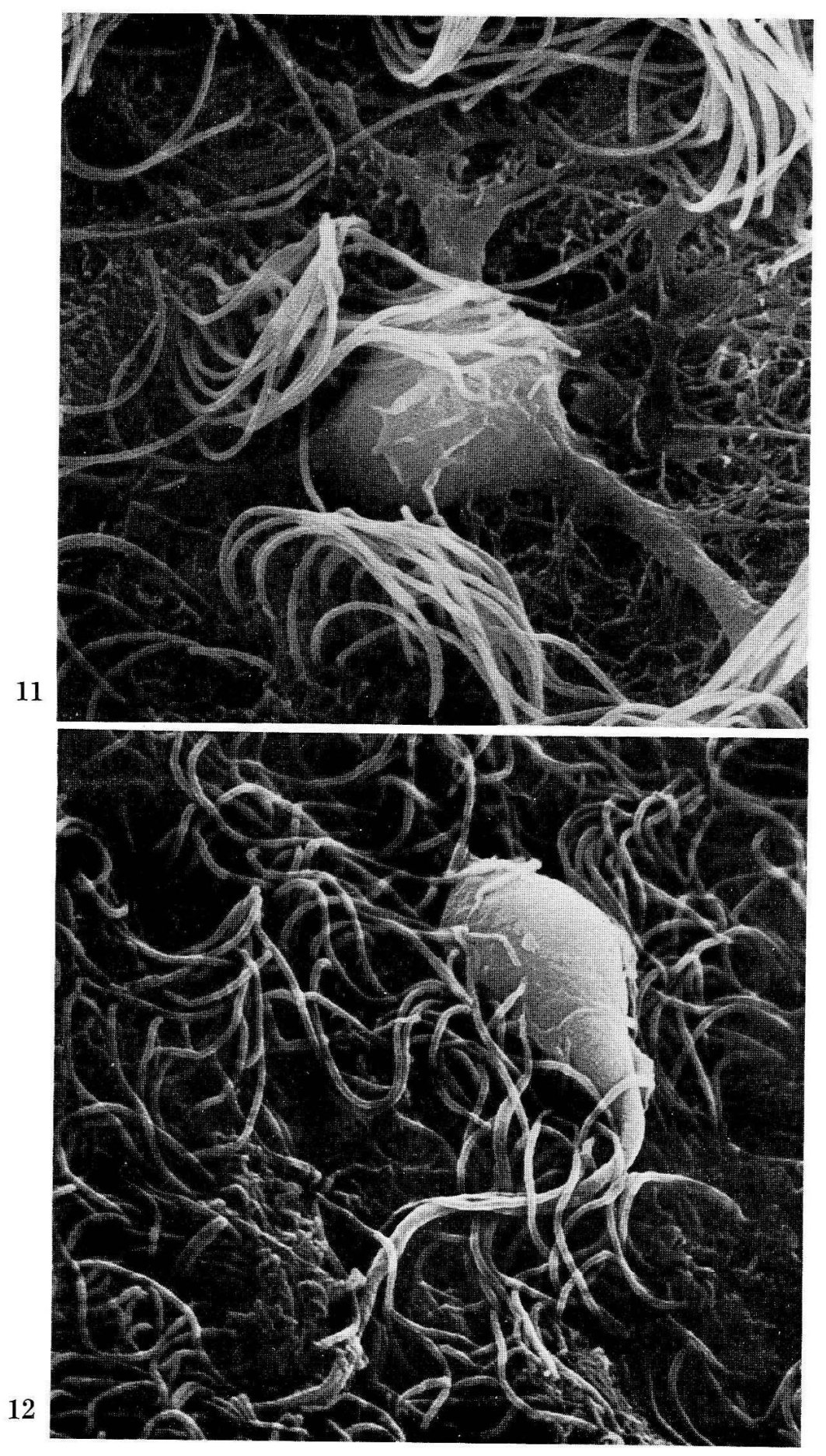


also seen in the cytoplasm. Golgi complex and multivesicular bodies are seen in the supranuclear portion (Fig. 13, 14), but lysosomes and lipid droplet-like substances are seen either in the supranuclear or basal portion. The latter seem to be finally secreted through the ependymal surface (Fig. 20). Mitochondria with dense matrices are numerous.

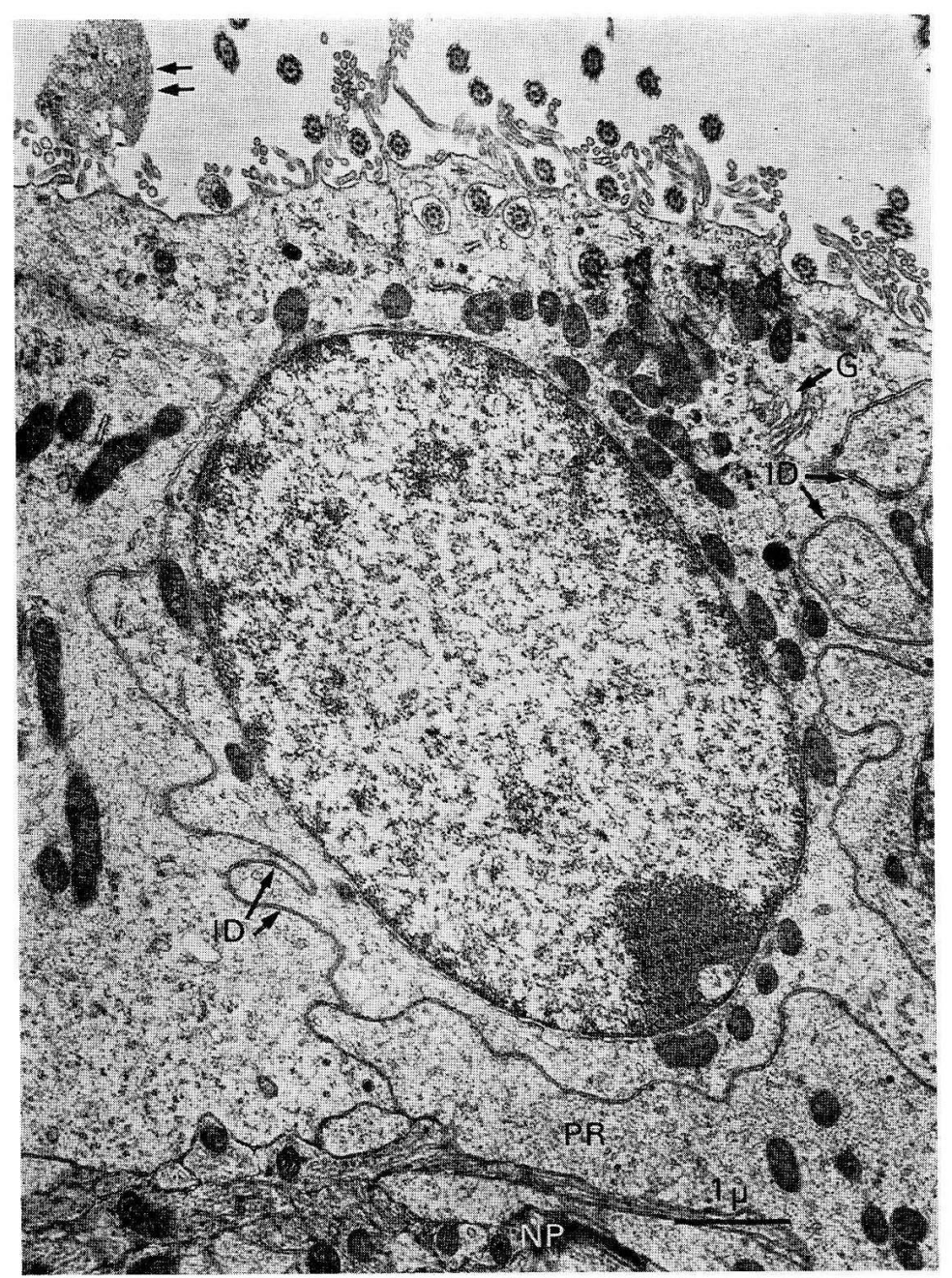

Fig. 13. TEM view of the ependyma. The ependymal cell has an oval nucleus and relatively light cytoplasm. Double arrows show detached cytoplasm of the ependyma. G Golgi complex, $I D$ interdigitation, $P R$ process of the ependymal cytoplasm, $N P$ neuropil.

Fig. 11. A supraependymal cell carrying many processes which branch many times and form a kind of network interwoven with similar processes. Frequently terminal parts of these processes seem flat. $\times 6,250$

Fig. 12. A spindle form neuron-like cell carrying bipolar processes which do not branch and never form a flat end. $\times 6,250$ 


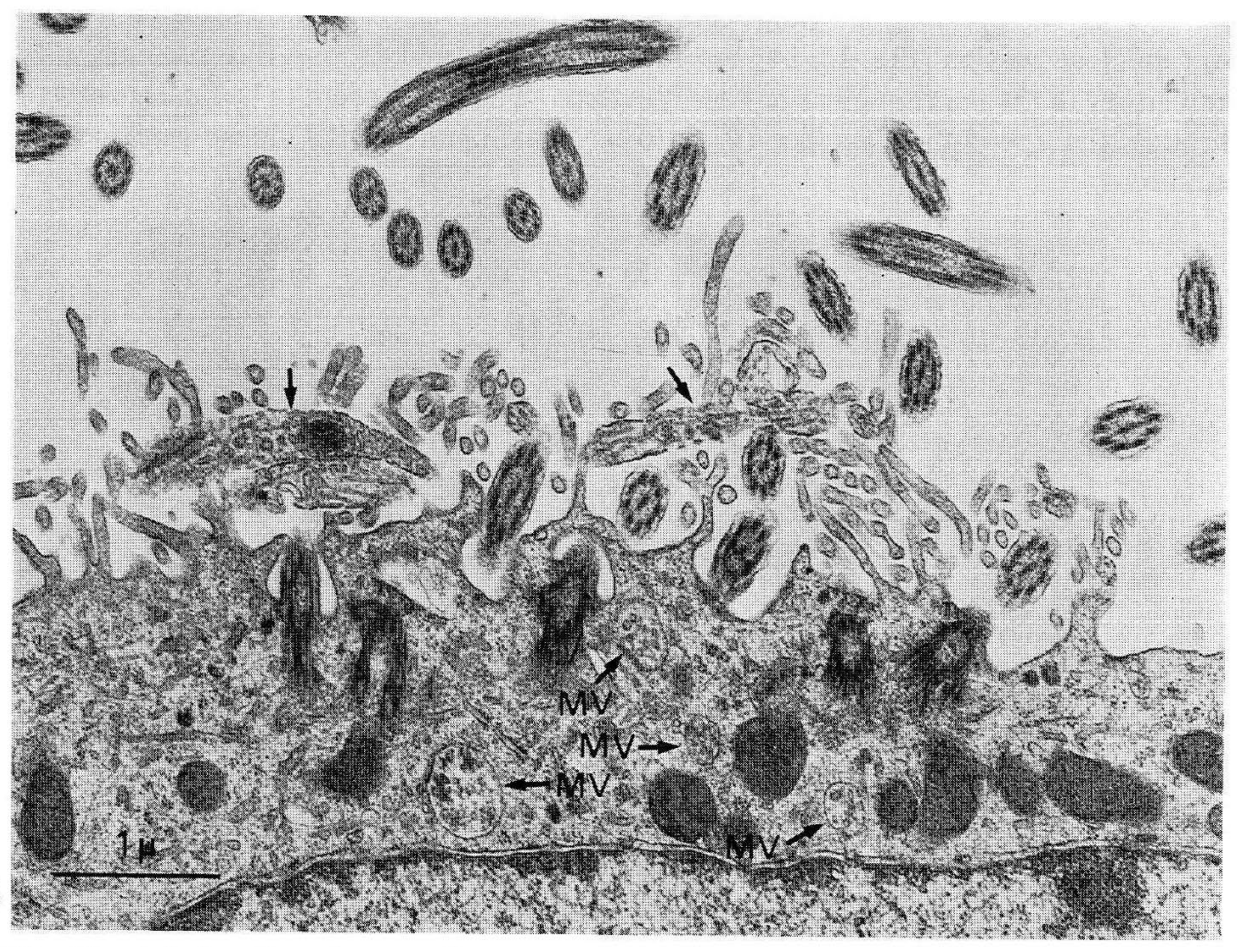

Fig. 14. Apical portion of an ependymal cell. Many microvilli and several cilia with basal bodies are seen. Multivesicular bodies $(M V)$ are also observable.
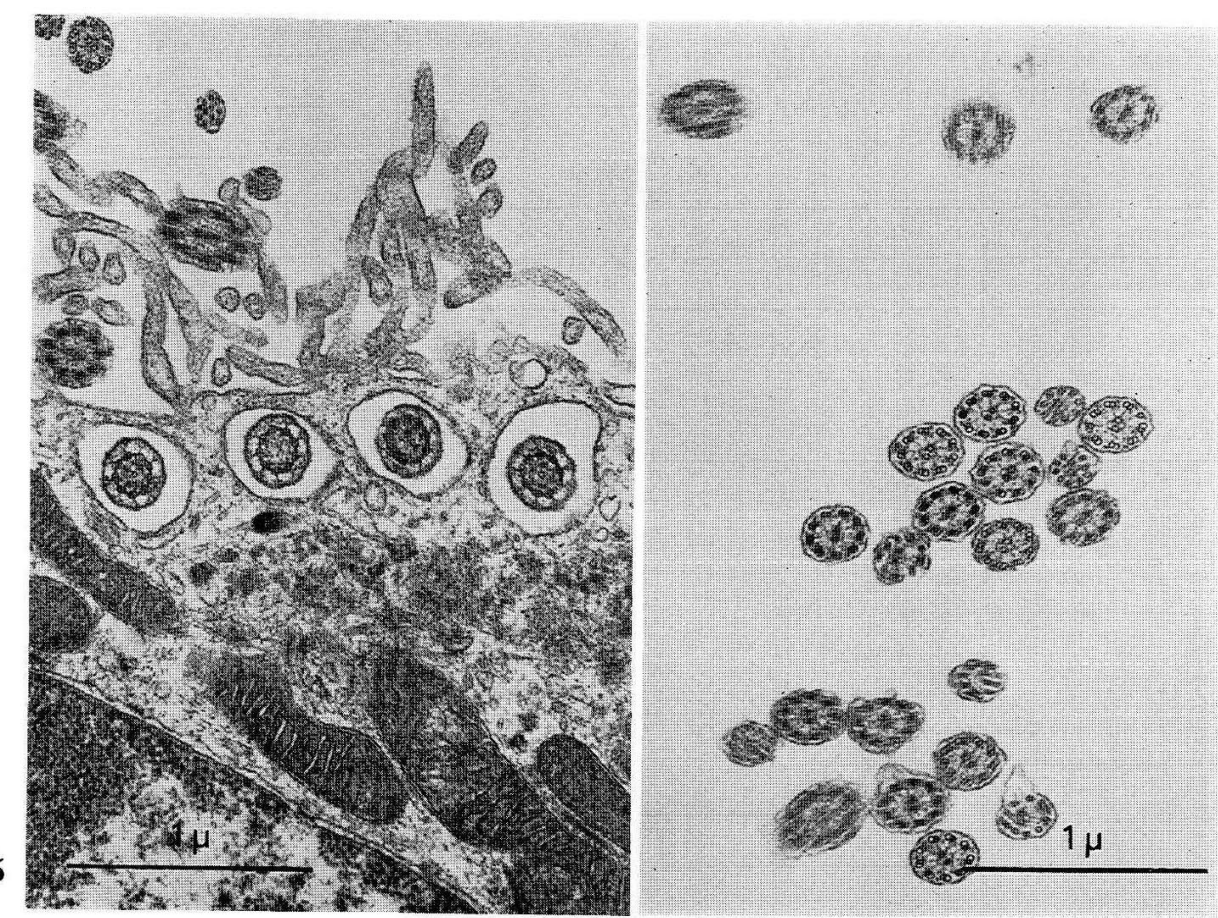

Fig. 15. and 16. Transverse sections of various parts of cilia. 


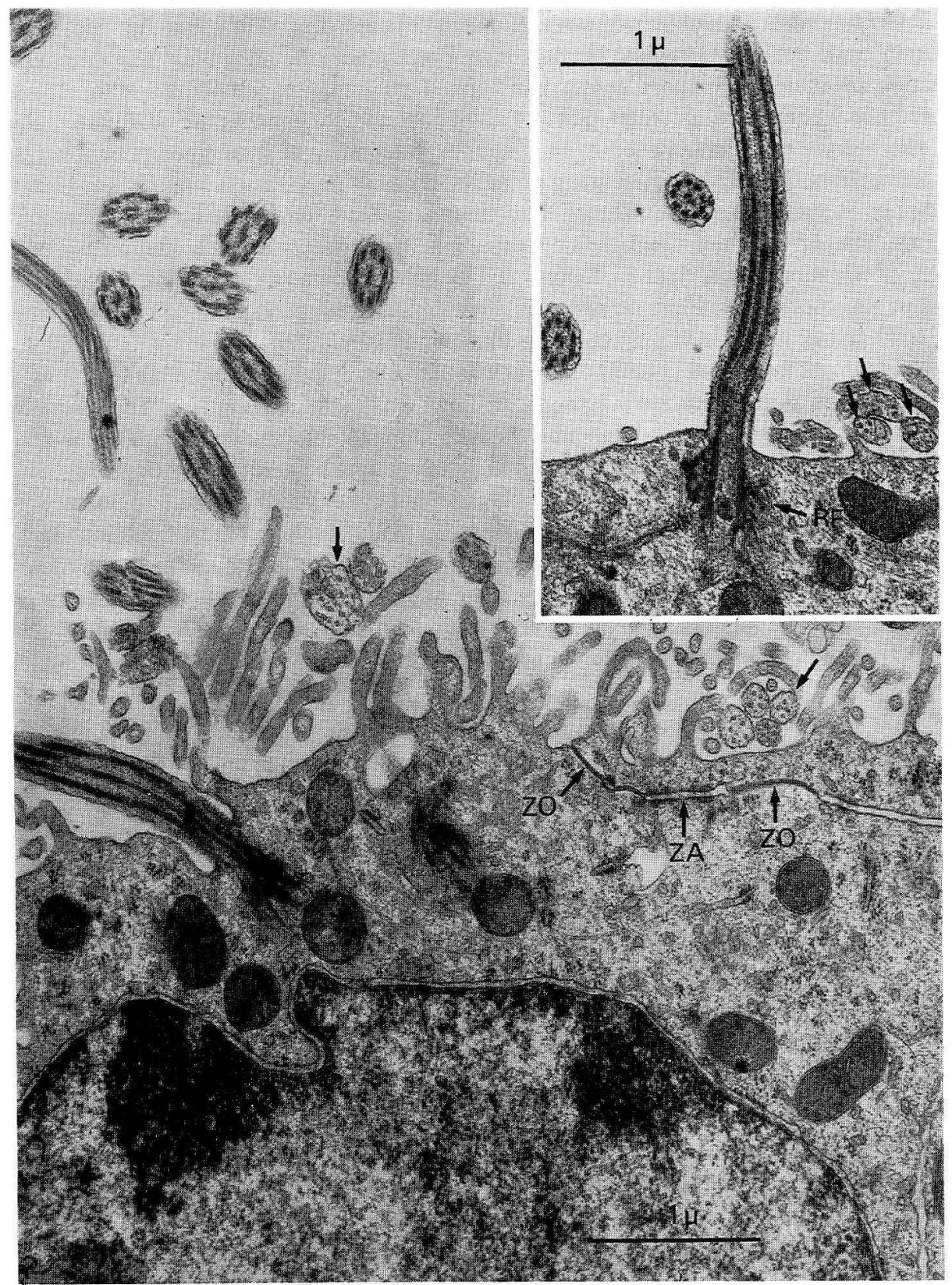

Fig. 17. Longitudinal section of a cilium. The most proximal portion of the ciliary shaft looks rigid and the plasma membrane of this portion has an indentation. $R F$ rootlet filaments.

Fig. 18. Apical portion of contiguous ependymal cells showing zonula occludens $(Z O)$ and zonula adhaerens $(Z A)$. Filaments in a microvillus are observable. Arrows show transverse sections of unmyelinated nerve fiber-like structures. 
On the ventricular surface, several dozen cilia are protruding into the ventricular lumen from the central apical portion of an ependymal cell (Fig. 14). The transverse section of the ciliary shaft shows the typical structure of kinocilium (Fig. 15, 16): there are 9 peripheral or outer pairs of fibers around a central pair of fibers. Each of the peripheral fibers is seen to be a doublet consisting of a subfiber $A$ bearing two short arms and a subfiber B bearing no arms (GibBons and Grimstone, 1960). Usually subfiber A contains a dense center but there seems to be no particular rule as sometimes both, or only the subfiber B contains a dense center. It is also not unusual that each of the subfibers is clear in content. The outer subfibers contact each other closely but the central subfibers do not. The other features correspond to the description of Brightman and Palay (1963), and Kohno and Usui (1966).

The most proximal portion of about $300 \mathrm{~nm}$ in length seems to be lacking in flexibility as this portion appears straight (Fig. 17, 18). The structure of this portion is somewhat different: the outer doublet sticks more closely and each doublet extends an arm to the neighbouring doublet, thus forming a link surrounding the inner doublet. The outer doublet projects a fine filament outward which seems to bifurcate just before attaching to the plasma membrane (Fig. 15). In a longitudinal section several transverse lines which supposedly correspond to the bifurcating spoke-like filaments are seen (Fig. 18). The outer surface of the plasma membrane at this portion seems to have indentations both in transverse and longitudinal sections (Fig. 15, 17, 18). This portion is not always encircled by the periciliary moat as it was described by
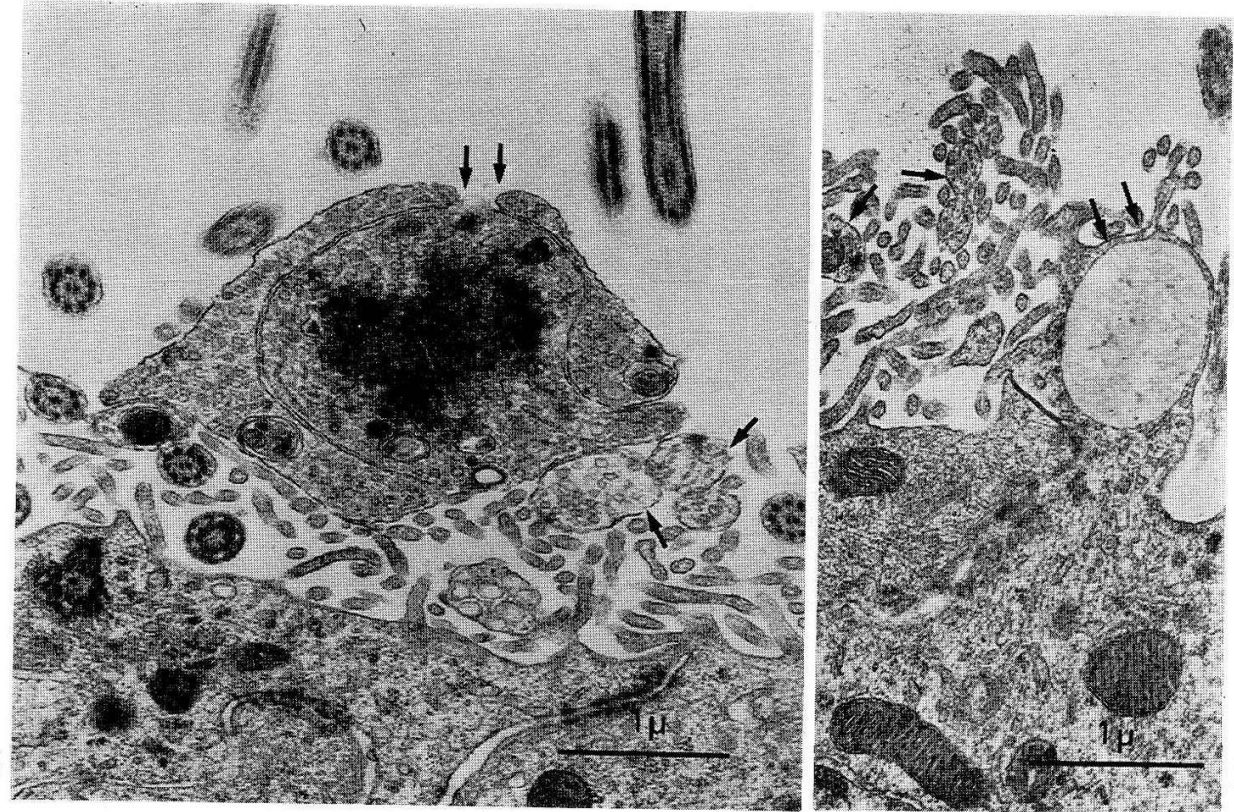

Fig. 19. A terminal bouton-like structure carrying numerous vesicles (double arrows). The vesicles in the central part have a dense content. Arrows show unmyelinated nerve fiber-like structures.

Fig. 20. A lipid droplet-like structure which seems just ready to be secreted into the ventricular lumen (double arrows). Arrows show unmyelinated nerve fiber-like structures. 
Brightman and PALAY (1963) (Fig. 17). When the cilium is transformed into a basal body in the cytoplasm, it loses the central doublet but is provided with rootlet filaments and a basal foot, and terminates at a depth of about $700 \mathrm{~nm}$ from the surface. The mitochondrial contact at the termination is seen quite often (Fig. 17, 18).

The lateral surface of each contiguous ependymal cell lies face to face within a distance of around $40 \mathrm{~nm}$. The contiguous surfaces form zonulae occludentes and zonulae adherentes to near the free surface but there seems to be no general principle determining which kind of them should be formed close to the ventricular surface (Fig. 18, 21). In the deeper portion the lateral cell surfaces are interdigitated (Fig. 13). Sometimes this interdigitation is seen even near the ventricular surface concurrent with the junctional complexes. The basal part of the ependymal cell seems to be

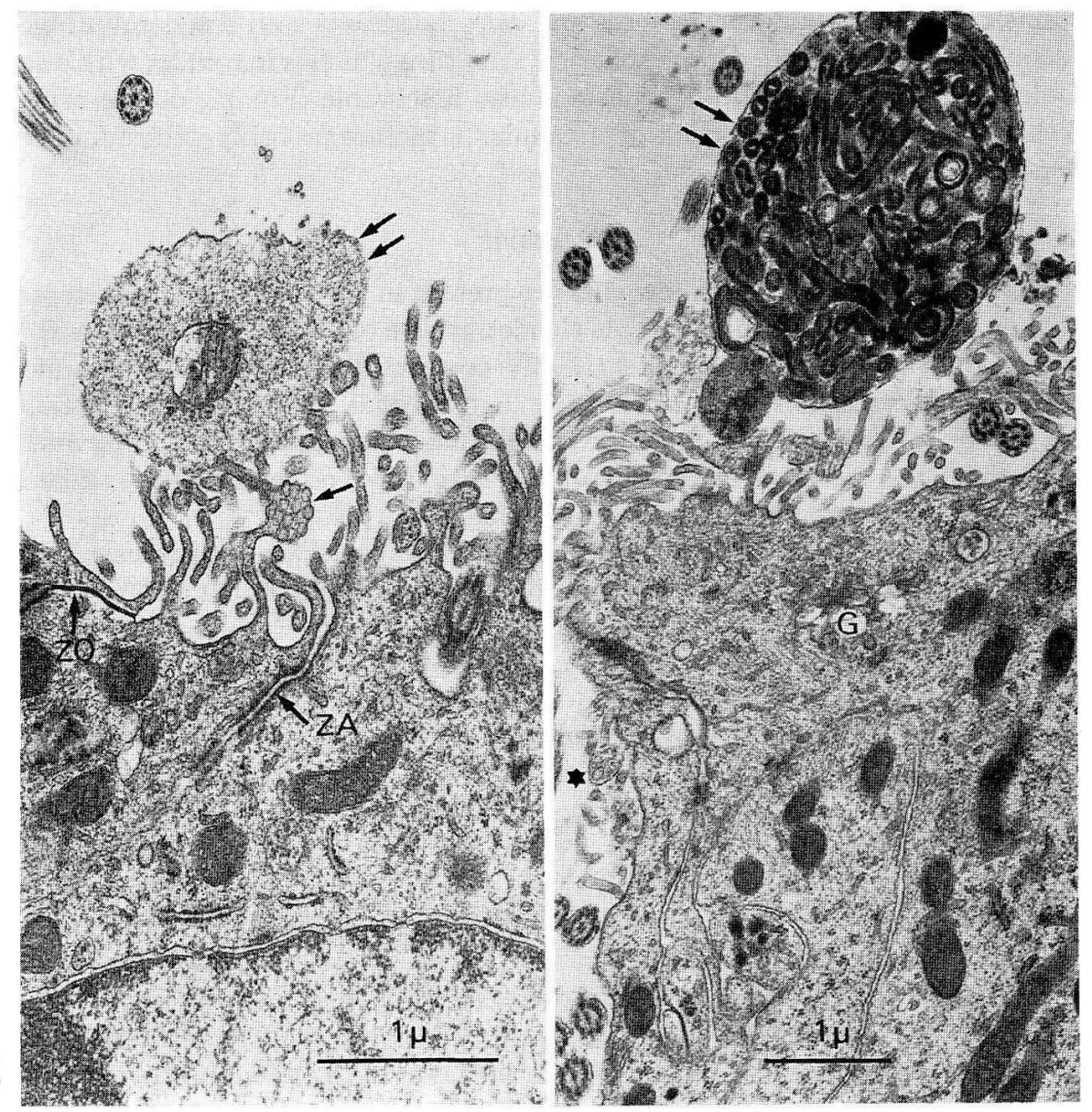

Fig. 21. A protruded portion of an ependymal cell containing only fine granular substaces and a mitochondria (double arrows). A swollen end of a microvillus containing only blebs is seen (arrow).

Fig. 22. A large spherule containing only mitochondria (double arrows). An asterisk shows a cavity on the ependymal surface. 
transformed into a few processes. The cytoplasm of these processes frequently seems very light, containing only filaments and mitochondria. As the ependyma has no basement membrane, it contacts directly with the underlying neuropil (Fig. 13).

A sectioned nerve cell or supraependymal cell could not be encountered on the ventricular floor under the transmission electron microscope. However, one could find many transverse sections of presumable unmyelinated nerve fibers or probable processes of the supraependymal cell containing several microtubules and a few mitochondria (Fig. 14, 17-20, arrows), and also sections of susceptible terminal boutons containing many synaptic vesicles. Figure 19 shows a large bouton-like structure which contains many dense vesicles in the center as well as many clear vesicles in the periphery, and this structure is further encircled by an envelope which also contains many clear vesicles. A protruded part of the ependymal cytoplasm which contains only fine granular substances and mitochondria is seen frequently (Fig. 13, 21 , double arrows). Rarely a large spherical structure which is in contact with a small globule and contains only mitochondria is also observable (Fig. 22, double arrows), and this is thought to be a portion of a cellular structure probably protruding from the subependymal layer.

\section{Discussion}

It is interesting that only a few cilia are present in the median sulcus in contrast to numerous cilia on both sides. This slender groove of about 10 to $40 \mu \mathrm{m}$ width is probably the site of the main current of the cerebrospinal fluid. The cilia of the ventricular floor bend generally toward the central canal, indicating the direction of the stroke permitting the flow of cerebrospinal fluid, but in the lateral aperture and in the area near the lateral aperture they bend laterally or posterolaterally. The distribution of cilia in the lateral part seems sparse.

The maximum diameter of a cilium is about $300 \mathrm{~nm}$ and this size agrees with that obtained by KoHNo and Usur in the rat (1966), ITAKURA in the rabbit (1972), and NAKAMURA et al. in the dog (1973). On the other hand Brightman and Palay (1963) reported it to be $400 \mathrm{~nm}$ in the rat, NoACK et al. (1972) to be $500 \mathrm{~nm}$ in the cat and Chamberlain (1973) to be $160-230 \mathrm{~nm}$ in the rat. Measurement of the exact length of a cilium is difficult but it can be figured out as around $10 \mu \mathrm{m}$ in the mouse and this is consistent with that measured by NoAcK et al. (1972) in the cat. However, BRIGHTMAN and PALAY (1963) reported it to be 15 to $20 \mu \mathrm{m}$ in the rat and ITAKURA (1972) to be $5 \mu \mathrm{m}$ in the rabbit.

The tip of the cilium is round and blunt. Chamberlain (1973) stated that some swelling occurred at the tip of the cilium during development. The oblate swelling observed in the median sulcus rather rarely (Fig. 8) seems like a tip of a cilium but the possibility that it is a tip of cellular protrusion from the ependymal layer corresponding to a mitochondria containing large spherical body by transmission electron microscopy cannot be neglected. As for the internal ultrastructure of the cilium, there seems to be nothing to add to the description of Brightman and PaLAy (1963), and KoHno and Usur (1966). However, the rule that the subfiber A has a dense center, the subfiber B has a clear content is not without exception.

In the median sulcus where cilia are scanty, numerous microvilli are observable on the ependymal surface (Fig. 8, 9), which has a diameter of about 50 to $90 \mathrm{~nm}$. They 
project irregularly and never form a brush border. Transmission electron microscopy reveals several longitudinally-running filaments arranged in a circle or at random in the microvillus sectioned transversely. Sometimes the tip of a microvillus bulges and contains many small vesicles (Fig. 20, arrow). This bulge probably corresponds to a small swelling at the tip of a microvillus seen under the scanning electron microscope (Fig. 8). The globules of various sizes seen by scanning electron microscope are probably substances secreted through the ependyma. Possibly the protruded or detached ependymal cytoplasm (Fig. 13, 21, double arrows) and lipid droplet-like substances which are going to be secreted (Fig. 20, double arrows) may correspond to these globules.

The adjacent ependymal cells are linked by zonulae occludentes and zonulae adhaerentes as well as by interdigitations. BRIGHTMAN and PALAY (1963) precisely described the former two junctional complexes but they did not recognize the interdigitation in the third and fourth ventricles of the rat. There seems to be no rule in arrangement of the above described two junctional complexes, except that they are always seen more close to the ventricular surface. In the basal portion a rough interdigitation is frequently recognizable. Very rarely a cavity formation on the ventricular floor is demonstrable by transmission electron microscopy (Fig. 22, asterisk). The meaning of this cavity is unknown but its surface has no particular features compared with that of other areas.

In many cases examined in the present study a long somewhat wavy or straight fiber running anteroposteriorly along the median sulcus is recognized. This is supposed to be a Reissner's fiber in the fourth ventricle (Fig. 7). Its diameter is about 1.0 to $3.0 \mu \mathrm{m}$ or more. Usually its outer surface seems smooth but the ultrastructure of its section was not observed by the authors.

As free cells which are found constantly in the ventricle, a few smooth surfaced spherical cells of about 3.0 to $4.0 \mu \mathrm{m}$ in diameter are observable (Fig. 10). Although the ultrastructure of their sections was not studied, they are assumed to be smooth lymphocytes. Besides these there are a few cells belonging to either supraependymal cells (CoAtes, 1973a, b; Mestres et al., 1974) or neuron-like cells. These cells are round, oval, triangular or polygonal in shape and have several processes which stick closely to the ventricular surface or probably go into the underlying ependymal layer. SchwANitz (1969) included these cells into supraependymal free cells, while CoATES (1973b) called these cells seen in the third ventricle of pig tail and rhesus monkeys as supraependymal cells and assumed that they are more neurosecretory in nature than neuronal, neuroglial, microglial or ependymal cells. Besides these supraependymal cells, there are bipolar or tripolar cells which are supposed to be neurons (Fig. 12). Clementi and Marini (1972), Noack et al. (1972) and Hosoya and Fuse (1973) suggested the possibility of the existence of neurons in the lateral and third ventricles. Brightman and Palay (1963), Takeichi (1966), Leonhardt and Lindner (1967), ROHRSCHNEIDER et al. (1972) and NoACK et al. (1972) reported unmyelinated nerve fibers upon or among the ependymal cilia in the whole ventricular system by transmission electron microscopy; most of these fibers may possibly belong to the processes of the supraependymal cells. However, the possibility that these supraependymal cells are neuronal in nature still can not be excluded.

Sectioned unmyelinated nerve fiber-like and terminal bouton-like structures are 
frequently encountered but a synapse as was seen by VIGH-TEICHMANN et al. (1970) in the third ventricle of some reptilia is not recognizable on the ventricular surface. Sometimes a large swelling which contains fine granules and one or two mitochondria named “Kugeln" by LeONHARDT and Lindner (1967), and named “ependymal bleb” by CoAtes $(1973 \mathrm{~b})$ are observable. This is supposed to be a large process of the ependymal cytoplasm as was pointed out by them. Its continuation with the ependymal cytoplasm is sometimes even recognizable. A large spherical body containing only numerous mitochondria recorded by TAKEICHI (1966) and LEONHARDT and PRIEN (1968) as a process of a nerve cell was observed in the present study. However, the continuation of this protrusion with a nerve cell underneath the ependymal layer was not ascertained.

\section{ハツカネズミ第四脳室底の走査型および透過型電子顕微鏡による観察}

$$
\text { ’山鳥崇と八木橋 操 六 }
$$

ハッカネズミの第四脸室底を走査型および透過型電子顕微鏡で観察した.

1. 第四脳室底ほ一層の上衣細胞によって出来ており，この上衣細胞の細胞質はフィ ラメントに富むが，リボゾームにはそしい.

2. 上衣細胞の脳室表面には多くの繊毛と微䋐毛がある. 脳室の内側部で この繊毛は 密であるが, 外側部では疎である。繊毛打の方向は内側部では 後方であるが，外側部で は後方または後内方である. また第四脳室外側口の近くでの繊毛打の方向は, 後外方ま たは外方である．正中溝では繊毛が極めて少い.

3. 繊毛は長さ約 $10 \mu \mathrm{m}$ またはそれ以上で，最も細胞表面に近い 屈曲性をもたない ように見える部分を除くと，基部がもっとも太く（直径 $300 \mathrm{~nm}$ ，先端でほわずかに細 くなる．先端は丸く鈍になつて終るが，少し曲っていることもある. 繊毛は動繊毛とし ての微細構造をもっている.

4. 隣接する上衣細胞は脳室表面の近くで閉鎖帯と接着带を, 深部では嵌合をつくる. 隣接細胞は 普通 約 $40 \mathrm{~nm}$ の距離を保っている.

5. 第四脳室表面では まれにリンパ球と思われる細胞や，その他の遊走細胞をみる が，ほかに数個の多形の上衣上細胞や神経細胞様の細胞が存在する．これらの細胞は双 極または多極の突起をもち，その断面は透過型電子顕微鏡では無骾神経線維様の構造と してみられる：これらの細胞の本体は不明であるが，少くとも あるものは 神経細胞で あろうと思われる。交た 稀に星状神経腤細胞によく似た細胞も認められる。

6. 第四脳室の表面で，ときに上衣細胞の突起や上衣細胞層の下の神経細胞から出た と思われる突起が認められる. 後者はその中に多数のミトコンドリアを含んでいる.ま た上衣細胞から分泌されたと思われる小顆粒が微䋐毛の間やその上に見られることがあ る. 


\section{References}

Barber, V. C. and A. Boyde: Scanning electron microscopic studies of cilia. Z. Zellforsch. 84: 269-284 (1968).

Brightman, M. W. and S. L. Palay: The fine structure of ependyma in the brain of the rat. J. Cell Biol. 415-439 (1963).

Bruni, J. E., R. E. Clattenburg and D. G. Montemurro: Ependymal tanycytes of the rabbit third ventricle: a scanning electron microscopic study. Brain Res. 73: 145-150 (1974).

Chamberlain, J. G.: Analysis of developing ependymal and choroidal surfaces in rat brain using scanning electron microscopy. Devel. Biol. 31: 22-30 (1973).

Clementi, F. and D. Marini: The surface fine structure of the walls of cerebral ventricles and of choroid plexus in cat. Z. Zellforsch. 123: 82-95 (1972).

Coates, P. W.: Supraependymal cells in recesses of the monkey third ventricle (1). Amer. J. Anat. 136: 533-539 (1973a).

-: Supraependymal cells: light and transmission electron microscopy extends scanning electron microscopic demonstration. Brain Res. 57: 502-507 (1973b).

Dalen, H., W. T. Schlapfer and A. Mamoon: Cilia on cultured ependymal cells examined by scanning electron microscopy. Exp. Cell Res. 67: 375-379 (1971).

Gibbons, I. R. and A. V. Grimstone: On flagellar structure in certain flagellates. J. biophys. biochem. Cytol. 7: 697-735 (1960).

Hirano, A. and H. M. Zimmerman: Some new cytological observations of the normal rat ependymal cell. Anat. Rec. 158: 293-302 (1967).

Hosoya, Y. and T. Fujita: Scanning electron microscope observation of intraventricular macrophages (Kolmer cells) in the rat brain. Arch. histol. jap. 35: 133-140 (1973).

Hosoya, Y. and S. Fuse: Scanning electron microscopic observation on the third ventricular wall of the rat. Acta anat. nippon. 48: 276-289 (1973).

Itakura, K.: Scanning electron microscopic observation on the ventricular wall and choroid plexus of the rabbit brain (In Japanese). Yonago med. J. 23: 404-411 (1972).

Kohno, K. and T. Usui: Electron microscopic studies on ependymal cilia and their basal feet on the ventral stalk of the rat subfornical organ. Bull. Tokyo Med. Dent. Univ. 13: 381-405 (1966).

Leonhardt, H.: Bukettförmige Strukturen im Ependym der Regio hypothalamica des III. Ventrikels beim Kaninchen. Z. Zellforsch. 88: 297-317 (1968).

Leonhardt, H. und E. Lindner: Marklose Nervenfasern im III. und IV. Ventrikel des Kaninchenund Katzengehirns. Z. Zellforsch. 78: 1-18 (1967).

Leonhardt, H. und H. Prien: Eine weitere Art intraventrikulärer kolbenförmiger Axonenendigungen aus dem IV. Ventrikel des Kaninchengehirns. Z. Zellforsch. 92: 394-399 (1968).

Mestres, P., W. Breiphol and G. J. Bijvank: The ependymal surface of the third ventricle of rat to hypothalamic area: a reflection scanning electron microscopic study. In: Scanning electron microscopy 1974. Chicago, IIT Research Institute, 1974 (p. 784-790).

Millhouse, O. E.: Light and electron microscopic studies of the ventricular wall. Z. Zellforsch. 127: 149-174 (1972).

Nakai, Y.: Fine structure and its functional properties of the ependymal cell in the frog median eminence. Z. Zellforsch. 122: 15-25 (1971).

Nakamura, S., Y. Yoshiyuki, T. Nakamura and N. Moriyasu: Ultrastructure of the ventricular wall in experimentally induced hydrocephalic dog (In Japanese). Brain and Nerve 25: 15831590 (1973).

Noack, W., L. Dunitrescu and J. U. Schweindel: Scanning and electron microscopical investigations of the surface structure of the lateral ventricles in the cat. Brain Res. 46: 121-129 (1972).

Rohrschneider, I., I. Schinko und R. Wetzstein: Der Feinbau der Area postrema der Maus. Z. Zellforsch. 123: 251-276 (1972). 
Schwanitz, W.: Die topographische Verteilung supraependymaler Strukturen in den Ventrikeln und im Zentralkanal des Kaninchengehirns. Z. Zellforsch. 100: 536-551 (1969).

Schinko, I., I. Rohrschneider und R. Wetzstein: Elektronenmikroskopische Untersuchungen am Subfornikalorgan der Maus. Z. Zellforsch. 123: 277-294 (1972).

Scott, D. E., W. K. Paull and G. K. Dudley: A comparative scanning electron microscopic analysis of the human cerebral ventricular system. 1. The third ventricle. Z. Zellforsch. 132: 203-215 (1972).

Takeichi, M.: The fine structure of ependymal cells. Part 1 . The fine structure of ependymal cells in the kitten. Arch. histol. jap. 26: 483-505 (1966).

Tennyson, V. M. and G. D. Pappas: An electron microscope study of ependymal cells of the fetal, early postnatal and adult rabbit. Z. Zellforsch. 56: 595-618 (1962).

Uemura, H. and H. Kobayashi: Functions of ependymal cells in the median eminence (In Japanese). Igaku no Ayumi 90: 937-944 (1974).

Vigh-Teichmann, I., B. Vigh und S. Koritsánsky: Liquorkontaktneurone im Nucleus paraventricularis. Z. Zellforsch. 103: 483-501 (1970).

Weindel, A. and R. J. Joynt: Ultrastructure of the ventricular walls. Arch. Neurol. 26: 420-427 (1972).

Yamadori, T. and K. Saito: A perfusion fixation technique for electron microscopy (In Japanese). Hirosaki med. J. 21: 571-578 (1970).

\author{
山鳥 崇 \\ $\overline{\mathbf{T}} 036$ 弘前市在府町 5 \\ 弘前大学医学部 \\ 第一解剖学教室
}

Dr. Takashi YAMADORI

First Department of Anatomy

Hirosaki University School of Medicine

Zaifucho 5, Hirosaki, 036 Japan 